\title{
Spatial mobility and tolerance towards immigrants: The case of Northern Iceland
}

\author{
Thoroddur Bjarnason* \\ University of Akureyri \\ Clifford Stevenson \\ Nottingham Trent University \\ Ian Shuttleworth \\ Queen's University Belfast \\ Markus Meckl \\ University of Akureyri
}

Published online in Ethnic and Racial Studies 2019,

https://doi.org/10.1080/01419870.2019.1667003

* Direct all correspondence to Thoroddur Bjarnason, Department of Social Sciences, University of Akureyri, 600 Akureyri, Iceland. thoroddur@unak.is 


\begin{abstract}
While the profound effects of spatial mobility on social structures and patterns of interactions have long been recognised, the association of mobility experiences and tolerance towards immigrants has received limited attention. In this paper, we examine such patterns in Iceland, a country with a long history of emigration and return migration of the local population but a recent surge in international immigration. We find in-migrants and locals who have lived in the capital city area or abroad for at least a year to be more tolerant of immigrants than locals who have never lived elsewhere. These patterns of tolerance among more mobile respondents persist after controlling for other predictors such as age, gender, education and language skills, employment status, income, community integration, residential satisfaction and generalised trust. These results are discussed in the context of changing patterns of mobility and immobility in western countries.
\end{abstract}

Keywords:

Immigrants; Residential mobility; Return migration; Tolerance; Local community; Iceland 


\section{Introduction}

The distinction between simple, close-knit and immobile traditional communities and complex, modern and spatially and socially mobile urban societies was central to classical social theorists such as Tönnies (1887), Durkheim (1893) and Simmel (1903). While these early theorists were deeply concerned over the social ills associated with modernisation, they shared a firm belief that increased tolerance towards social and interpersonal differences was inevitable in large, complex societies.

The role of geographical mobility in the breakdown of normative consenus and social control was explicitly outlined by the "Chicago School" of social ecology (Park and Burgess 1925; Shaw and McKay 1942). As the inflows and outflows of people changed the demographic and social composition of areas, crime rates tended to be high in urban "transition zones" characterized by heterogeneity, rapid rates of population turnover and weak and conflicting social norms. More recent work has also shown that internal migration - residential moves within the same country - sorts the population by race, ethnicity, health, religion and social class (Bailey 2012; Catney and Simpson 2010; Shuttleworth et al. 2013) although the precise size of the effects remain a matter for debate. Increased spatial mobility over the long term has thus been seen as an important part of the transformation of neighbourhoods, social structures, individual identities and social patterns of interaction.

There has been far less attention paid to the experiences and attitudes of people who remain in place while their neighbourhoods and the wider world changes around them. This paucity of research is all the more relevant as there is growing evidence that internal migration is slowing down across the developed world (Champion et al. 2018). Considerable work is still needed to understand why people are not changing address as frequently as they did in the 1970 s or 1980s but there is already some evidence of the possible political and social implications of residential immobility. Recent analyses of the UK's 2016 Brexit vote (Lee et al. 2018), for instance, show that people who still resided in their county of birth were more likely to vote Leave than individuals who had moved between counties. Similarly, in the United States, one of the variables associated with voting Trump, which appeared to act independently of race, income or education, was whether a person had left their home town (Goodhart 2017). Once again, those who had stayed put tended to be less trusting, less open to change, and to hold more conservative social and political attitudes.

In this paper we explore the individual-level effects of migration experiences on tolerance towards immigration by means of a questionnaire survey of the residents in Northern Iceland to explore. Specifically, we examine differences in tolerance towards immigrants between residents who have never lived elsewhere, locals who have returned to their home communities after living in the city or abroad for at least a year, and "blow-ins" or inmigrants without prior ties to the communites. In the analysis we take into account sociodemographic factors such as place of residence, age, gender, education, employment status as well as attitudinal factors such as generalised trust, community integration and residential satisfaction.

\section{Attitudes towards immigration and residential mobility}

The predictors of attitudes towards immigration have been studied extensively across the social sciences: the impact of political, economic and policy contexts upon popular responses to immigration have been examined in times of prosperity and austerity (e.g. Hatton 2016; Wilkes and Corrigall-Brown 2011), the demographic and geographical distribution of antiimmigrant sentiment within and between nations has been mapped (e.g. Bello 2016; Ueffing et al. 2015; van der Zwet 2016) as have the effects of local neighbourhood contexts on individual attitudes (Van Assche et al. 2014). At the individual level, differences in 
personality types, social identities and related attitudes have been surveyed, as have individuals' localised perceptions and experiences of immigration and contact with individual immigrants (Voci and Hewstone 2003; Schmid et al. 2014).

However, it remains unclear how individual-level mobility shapes receptiveness to immigration. Movers are self-selecting, coming from specific age, education and employment categories. Moreover, they may have pre-existing personality traits that pre-dispose them to move (Jokela 2009) and which are also correlated with greater trust and openness as well as demographic characteristics such as age and educational attainment. They can move for reasons related to their attitudes to immigration and may relocate to new communities who could hold similar or different beliefs. In doing so, they are likely to disrupt their sense of local rootedness, leave behind their previous neighbourhood influences and be exposed to many of the different experiential factors known to reshape attitudes.

\section{Demographic and Contextual Influences on Attitudes towards Immigration}

While the effects of age on attitudes towards immigrants tend to be small, older people have generally been found to be less tolerant of immigrants (e.g. Bridges and Mateut 2014; Markaki and Longhi 2013). While many studies have found women to be less tolerant of immigrants (e.g. Amuedo-Dorantes and Puttitanun 2011; Berg 2010; Hainmueller and Hiscox 2007), some studies have found the opposite to be true for certain measures of intolerance (e.g. Bridges and Mateut 2014; Markaki and Longhi 2013).

Higher education tends to be more reliably associated with more positive attitudes towards immigration (Easterbrook et al. 2016; Hainmueller and Hiscox 2007). Multilingualism also enables nationals to converse with immigrants and reflects a degree of exposure to cultural difference and cognitive flexibility which predicts more positive attitudes towards immigrants (Mepham and Martinovic 2018).

Demographic characteristics in turn reflect social structural inequalities which shape public attitudes to immigration. Individuals of higher socio-economic status (SES) tend to be more concerned over immigration as a potential burden upon the welfare state, while those with lower SES are more likely to perceive immigration as a direct threat to jobs (Naumann et al. 2018; Söllner 1999). This effect is attributable to individual-level job insecurity, with trade union membership and associated job security predicting more positive attitudes to immigration (Gorodzeisky and Richards 2016). Similarly, high SES individuals remain unthreatened by high-skilled immigration (O'Connell 2011), though retirement is notably not necessarily accompanied by a liberalising of attitudes (Jeannet 2018).

Cultural threat is equally complex, with host nationals adjudicating the compatibility of incoming cultures alongside the willingness and ability of immigrants to acculturate (e.g. Roblain, Azzi, and Licata 2016; Zagefka et al. 2007). While cultural threat can coincide with economic threat, the two are dissociable (Ben-Nun Bloom et al. 2015; Dustmann and Preston 2007) with culturally threatened nationals preferring immigrants who are similar to them, while economically threatened nationals prefer immigrant groups who are different as they will not compete for the same resources.

\section{Dispositional and Experiential Influences on Attitudes towards Immigration}

From a psychological perspective, individuals exhibit differences in attitudes to immigrants and immigration according to their individual personality types, with openness to experience predicting more tolerance (Freitag and Rapp 2015) and authoritarianism less tolerance (Van Assche et al. 2014) towards immigrants. Individuals' perceptions and relationships with others also shape attitudes to immigration. Higher levels of social capital, in the form of generalised social trust among host nationals across Europe is predictive of more positive 
attitudes towards immigration (Herreros and Criado 2009). At a local level, a sense of belonging and integration within one's local and national communities has for instance been found to predict more positive attitudes towards immigration in South Africa (Gordon 2015; Gordon and Maharaj 2015) and towards incomers from religious outgroups in Northern Ireland (Stevenson et al. 2018). However, at the same time, exclusive or territorialised understandings of belonging can undermine these effects (Stevenson and Sagherian-Dickey 2018; Van Assche et al. 2014).

While segregation and absence of contact with immigrants is typically associated with poorer attitudes towards immigrant groups (Voci and Hewstone 2003), residential diversification can lead to either higher levels of prejudice or better intergroup relations groups (Schmid et al., 2014). The experience of residential diversification has been linked to reduced social capital and increased perceptions of threat, which in turn can predispose host nationals to negative experiences of contact with immigrants (Stephan 2014). Positive contact can however have positive effects on attitudes towards the immigrant and their group more generally (Voci and Hewstone 2003).

\section{Consequences of residential mobility}

Relocation has a profound impact on sense of community belonging and identity as well as upon social networks and group memberships. Residing within one's place of origin may contribute substantially to one's sense of attachment to local community as well as place identity (Hernández et al. 2007). These feelings of connectedness and belonging are likely to be lower among those who move (Abrams and Emler 1992) and, in turn, the loss of immediate connection with one's place of origin is likely to diminish its importance for one's self concept (Hernández et al. 2007).

Similarly, relocation typically exposes movers to a greater variety of worldviews and possibilities than does a static existence. In effect, mobility increases the likelihood of positive intergroup contact and this increased exposure to new experiences and diversity often leads to a reappraisal of ones' ethnocentric worldview and a decrease in identification with one's community of origin (Pettigrew 1998; Verkuyten, Thijs, and Bekhuis 2010). In addition, moving from a location in which multiple group memberships coincide (e.g. ethnicity, religion, political ideology, sexual orientation) to an area where these groups evidence more heterogeneity and diversity can also lead to a more nuanced and inclusive sense of identity. This 'identity complexity' (Schmid et al. 2013) recognises the variety of diversity within groups as well as overlaps between them and has been linked to greater levels of inclusion and tolerance of outgroups.

Of course, not all moves are equivalent in terms of distance or destination. Rural-urban migration poses some challenges to migrants, both in terms of fitting into their new locales or returning to their places of origin (e.g. Du 2017; Stockdale et al. 2013). However, returning from abroad poses even more significant challenges to reintegration, especially within more traditional communities where authenticity and commitment to locale and culture may signify belonging (Andits 2017; van Houte and Davids 2018) and where there may be significant clashes between cultures and values (e.g. Passche 2016). Returnees may therefore need to creatively engineer and deploy new identities to reconcile their histories with the demands of their destination communities.

Moving over a certain distance is likely to strain work, leisure and family relationships (Praharso et al. 2017). While residential moving shares similarities with other life transitions, the simultaneous loss of multiple group memberships marks it as relatively unique (Oishi and 
Schimmack 2010; Praharso et al. 2017). In effect, movers are stripped of the various sources of support, information and identity which define their previous existence.

\section{Expected Implications of Residential Mobility for Attitudes towards Immigration}

Based on the considerations outlined above, we expect prior residential mobility to be associated with greater tolerance towards immigration. This could in part be an effect of greater exposure and appreciation of ethnic and cultural diversity. In addition, the experience of being or having been an in-migrant can be expected to increase sympathy with immigrants in the local community. However, this could also in part be due to a selection effect where people with greater tolerance of ethnic and cultural diversity are more likely to be residentially mobile (Jokela 2009). While the complex feedback loops between personality, demographic characteristics, attitudes and behaviours are clearly beyond the scope of the current study, we expect to find differences in attitudes between stayers who have never lived elsewhere, local return migrants and other in-migrants from either the city or other countries.

In addition, we expect certain socio-demographic and attitudinal patterns of tolerance to intersect with migration experiences. As noted above, movers are more likely to be working age, more affluent and more educated. Individuals with permanent jobs should be less economically threatened by either low-skilled or high skilled migrants as well as being less concerned with cultural threat. A university education may be associated with more liberal attitudes towards immigration, but a university degree may involve either in-migration or return migration. In addition, in non-English speaking countries a university education can be expected to be associated with proficiency in English, directly facilitating comunication with immigrants that are not proficient in the host country language. Given evidence of wide contextual variations, we did not make specific predictions about the effects of gender and age upon attitudes towards immigration.

Social integration and bonding social capital may have strong but conflicting impacts on attitudes towards immigrants. On one hand, individuals who have never lived elsewhere and have strong ties with the local community may hold negative outgroup attitudes and resent changes to the composition of the community. At the same time, feeling securely embedded with one's locale and general trust in others can be expected to be associeted with being less threatened by immigration.

\section{Data and Methods}

\section{Northern Iceland as a Case}

Iceland currently has a opulation of about 350,000 inhabitants. The majority of this is located around the coastal fringe with more than 200,000 residing in the southwest Reykjavik Capital Area. All other regions have a net loss of people with the Capital Area through migration but immigration from overseas has led to population growth in most parts of the island, despite falling fertility rates.

As shown in Figure 1, the current study focuses on three towns in central Northern Iceland (Mið-Norðurland), approximately $400 \mathrm{~km}$ from the Reykjavík capital area. In 2016, the whole of Northern Iceland had a population of about 36,800 inhabitants, of which about 18,000 lived in the regional centre of Akureyri. Dalvík, $44 \mathrm{~km}$ to the north had a population of about 1,400, while Húsavík, $91 \mathrm{~km}$ to the east had a population of about 2,200. The 26 other towns and villages in Northern Iceland had a combined population of about 9,600 while about 5,600 lived in sparsely populated farming communities. 


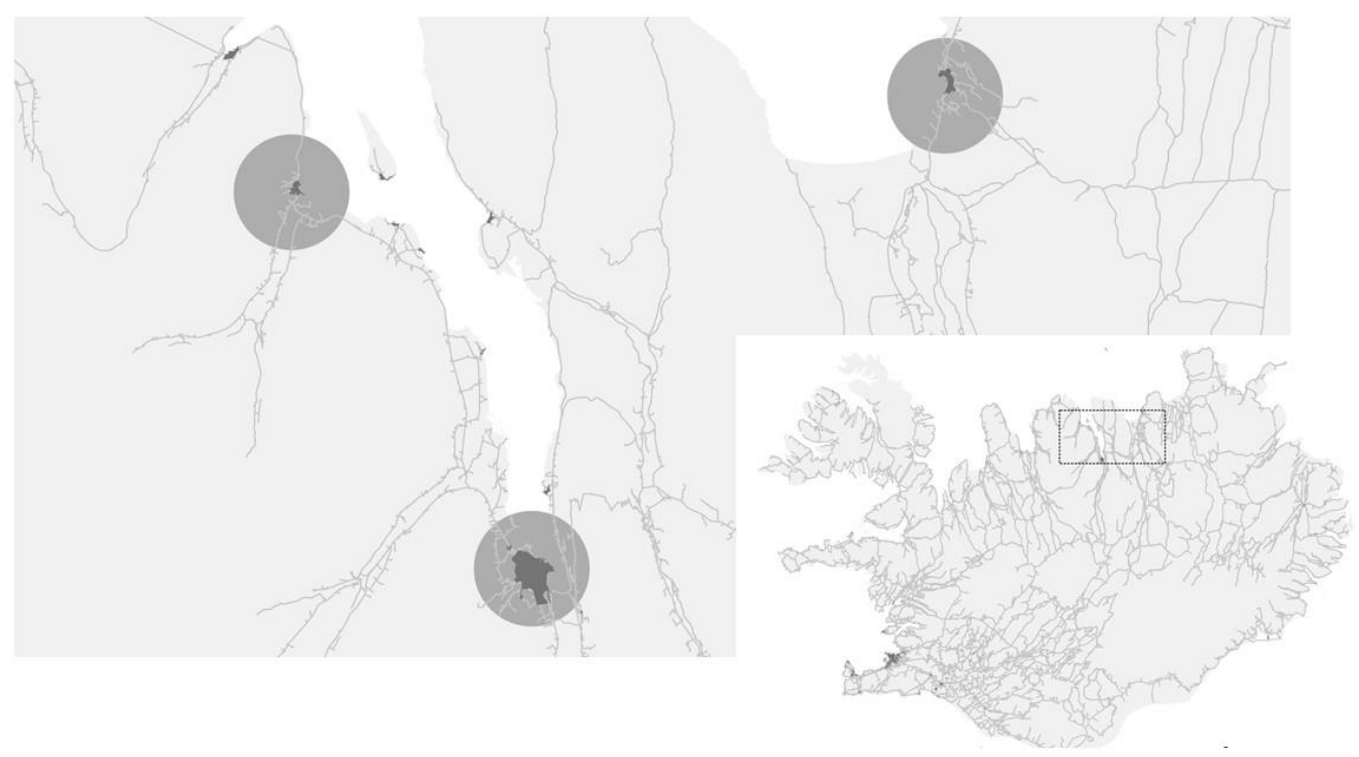

Figure 1 Central Northern Iceland and the communities under study

Between 1996-2016, the population of immigrants in these three towns grew from about 300 to about 2.100 while the non-immigrant population correspondingly declined to keep population numbers steady. In 1996, immigrants represented less than $1 \%$ of the total population, compared to $2 \%$ nationwide. In 2016, the immigrant population was $5 \%$ in Akureyri, $8 \%$ in Húsavík and $12 \%$ in Dalvík, compared to $11 \%$ nationwide. The case study region has therefore experienced considerable recent demographic change through immigration but has not experienced the rapid economic growth and population growth of the Reykjavik region.

\section{Sampling and data collection}

This research is based on data collected in Spring 2016 as part of the Community and Welfare in Northern Iceland research project. The data were collected in the three largest towns in Northern Iceland; Akureyri, Dalvík and Húsavík. These three towns include 59\% of the population of Northern Iceland in 2016 (Statistics Iceland 2019a).

Paper questionnaires were hand delivered to addresses and all adult residents invited to participate. The sampling frame included all addresses in Dalvík and Húsavík while 60 streets were randomly selected in the larger regional centre of Akureyri. The random sample of streets in Akureyri was drawn from a list of all 191 residential street names in Akureyri. A random number generator was used to choose 60 streets from the list. Research assistants visited all single-residence houses or apartments in multi-residence houses on these streets and invited all residents 18 years or older to participate in the survey. If nobody answered the door, research assistants returned twice at different times over a period of one week.

The survey providing data for this study was aimed at the Icelandic-born population, yielding 1,758 responses from individuals raised in Iceland. The response rates were about $29 \%$ among the non-immigrant target population in Akureyri, 54\% in Dalvík and 21\% in Húsavík. Compared to official registration data provided by Statistics Iceland (2019a), males were slightly under-represented ( $44 \%$ in the sample compared to $49 \%$ in the population). The age group 18-25 year old also appears to be underrepresented (9\% in the sample compared to $15 \%$ in the population), although prior research suggests that the official registry 
overestimates the number of young people actually living in rural areas in Iceland (Bjarnason and Olafsson 2014).

The outcome variable measured tolerance towards immigrants and the central focus was how this was related to spatial mobility histories. Controls were made for other independent variables that the literature indicated were associated with attitudes of tolerance/trust towards immigrants. These included education, age, labour market status, and broader attitudes towards community integration, residential satisfaction, and generalised trust. Many of these variables are also associated with mobility intentions and spatial mobility behaviour, in particular residential satisfaction, education, age and employment status.

\section{Model and Measures}

Table 1 shows an overview of the measures used in this study. About $57 \%$ of the sample was from the regional centre of Akureyri, about 17\% from Húsavík and about 26\% from Dalvík. With 18,000 inhabitants, Akureyri is five times larger than the other two towns combined. It is an urban centre with various regional services and employment opportunities, including e.g. the regional hospital, a small independent university, shopping mall, and cafés, bars and restaurants. The 5\% immigrant population in Akureyri is however less than half the national average of $11 \%$ while the proportion in other two towns is close to the national average. As the purpose of the study is to study general processes rather than provide point estimates for the participating communities, the data were not weighted to reflect the relative size of the three towns. Instead, dummy variables were included for Húsavík and Dalvík to control differenes in tolerance levels between residents of the three towns.

Females were significantly overrepresented in the sample. They were $56 \%$ of the respondents compared to $51 \%$ of the population (Statistics Iceland 2019a). The proportion of respondents aged 41-66 year old was also significantly higher in the sample than according to official registration data while the proportion of respondents aged 18-25 years old was 9\%, compared to $15 \%$ in the population according to Statistics Iceland (2019a). However, prior research has demonstrated that offical registration overestimates the number of young people in rural Iceland (Bjarnason and Ólafsson 2014).

University education is a binary variable recoded from a six response categories of educational attainment. Self-reported English proficiency is measured on a five point scale (1: Not at all; 5: Excellent).

Not being employed was recoded as a binary variable from a question of labor market participation (1: Not employed; 0: Other). Self-reported income is measured on a six-point scale (1: Less than 100 thousand ISK per month; 6: More than 900 thousand ISK per month).

Generalised trust was measured with responses to the question "Do you think most people can be trusted or can never be too careful about people?" with eleven response categories $(0$ : Can never be to careful; 10: Most people can be trusted).

Community integration was measured with a summary scale $(\alpha .=.88)$ of three items; (1) "My relationships with other townspeople are very important to me"; (2) "I can get assistence from other townspeople if I need help"; and (3) "I have similar views towards life as other townspeople" with five response categories (1: Totally disagree; 5: Totally agree).

Residential satisfaction was measured with responses to the question "Overall, how satisfied or dissatisfied are you with living in [town name]?” with five response categories (1: Very dissatisfied; 5: Very satisfied).

\section{Table 1}


Descriptive statistics for measures in three communities in Northern Iceland

Community

Akureyri regional centre (contrast)

Range

Mean

s.e.

st.dev

Húsavík

$(0-1)$

.568

.012

.495

$(0-1)$

.174

.009

.379

Dalvík

$(0-1)$

.258

.010

.438

Gender

Male (contrast)

$(0-1)$

.440

.012

.496

Female

$(0-1)$

.560

.012

.496

Age

18-25 years old

$(0-1)$

.101

.007

.301

26-40 years old

$(0-1)$

.250

.010

.433

41-66 years old (contrast)

$(0-1)$

.484

.012

.500

67 years old or older

$(0-1)$

.009

.379

\section{Education}

University education

English proficiency

.308

.010

.462

.500

\section{Employment}

Not employed

Income

$$
(0-1)
$$

$(-.09-1.3)$

$$
.229
$$

.012

.420

.500

\section{Attitudes}

Generalised trust

$$
(-1.1-0.7)
$$

.000

.010

.012

$(-2.1-0.7)$

.012

.500

Community integration

$(-1.4-0.5)$

$.000 \quad .012$

.500

$.000 \quad .012$

.500

\section{Lived in capital area for year or more}

$\begin{array}{lcccc}\text { Grew up in local community } & (0-1) & .216 & .010 & .412 \\ \text { Grew up elsewhere } & (0-1) & .238 & .010 & .426 \\ \begin{array}{l}\text { Lived abroad for year or more } \\ \text { Grew up in local community }\end{array} & (0-1) & .119 & .008 & .323 \\ \text { Grew up elsewhere } & (0-1) & .116 & .008 & .320 \\ \begin{array}{l}\text { Dependent variable } \\ \text { Tolerance towards immigrants }\end{array} & (1-10) & 6.840 & .042 & 1.764\end{array}$

Experiences of living elsewhere were measured with three different questions. Never having lived elsewhere is coded from responses from the question "How long have you lived in [town name]?". The two measures of having lived in the capital area or abroad for more than a year are derived from the questions "Have you lived in the capital area?" and "Have you lived abroad?" (0: I have not lived there; 1: Less than a year; 6: More than 20 years).

All continious independent variables are centred with a mean of zero and a standard deviation of 0.5. The effects of two standard deviations on each continious independent variable are thus directly comparable to the effects of each binary independent variable on tolerance towards immigrants.

The dependent variable of tolerance towards immigrants is based on a ten-point scale $(\alpha .=$ .88) constructed from two items; "Do you agree or disagree that it is good for [town name] 
that people from other countries settle here?" (1: Totally disagree; 5: Totally agree) and "Do you agree or disagree that more foreign immigrants should be encouraged to settle in [town name]?" (1: Totally agree; 5: Totally disagree). The correlation between the two items was .54 .

\section{Results}

Figure 2 provides and overview of the mobility of residents in the three communities. Overall, only $14 \%$ of the respondents had never lived elsewhere, with no statistically significantly differences between the three communities $\left(\chi^{2}: 5.1(2)\right.$, p. $\left.>.05\right)$.

About $60 \%$ of the respondents grew up in the current community, with a statistically significant $\left(\chi^{2}: 5.1(2)\right.$, p. $\left.>.05\right)$ difference from $57 \%$ in Akureyri to $65 \%$ in Húsavík. A comparison of the first two sets of figures thus reveals that about $46 \%$ of the respondents were originally from the communities but had lived elsewhere for at least a year.

About $46 \%$ of the respondents had lived in the capital area and $24 \%$ had lived abroad. The proportion of Dalvík residents that had lived in the capital area was significantly $\left(\chi^{2}: 12.1(2)\right.$, p. $>$.01) lower than in the other two communities and the proportion of Akureyri residents who had lived abroad was significantly higher $\left(\chi^{2}: 10.1(2), \mathrm{p} .<.01\right)$. The final set of figures shows that $17 \%$ of the respondents had lived both in the Reykjavík capital area and abroad with a statistically $\left(\chi^{2}: 10.4(2)\right.$, p. $\left.<.01\right)$ higher rate of $19 \%$ in Akureyri than the other two communities. It should thus be noted that only $7 \%(24 \%-17 \%)$ of the respondents had lived abroad but not in the capital area.

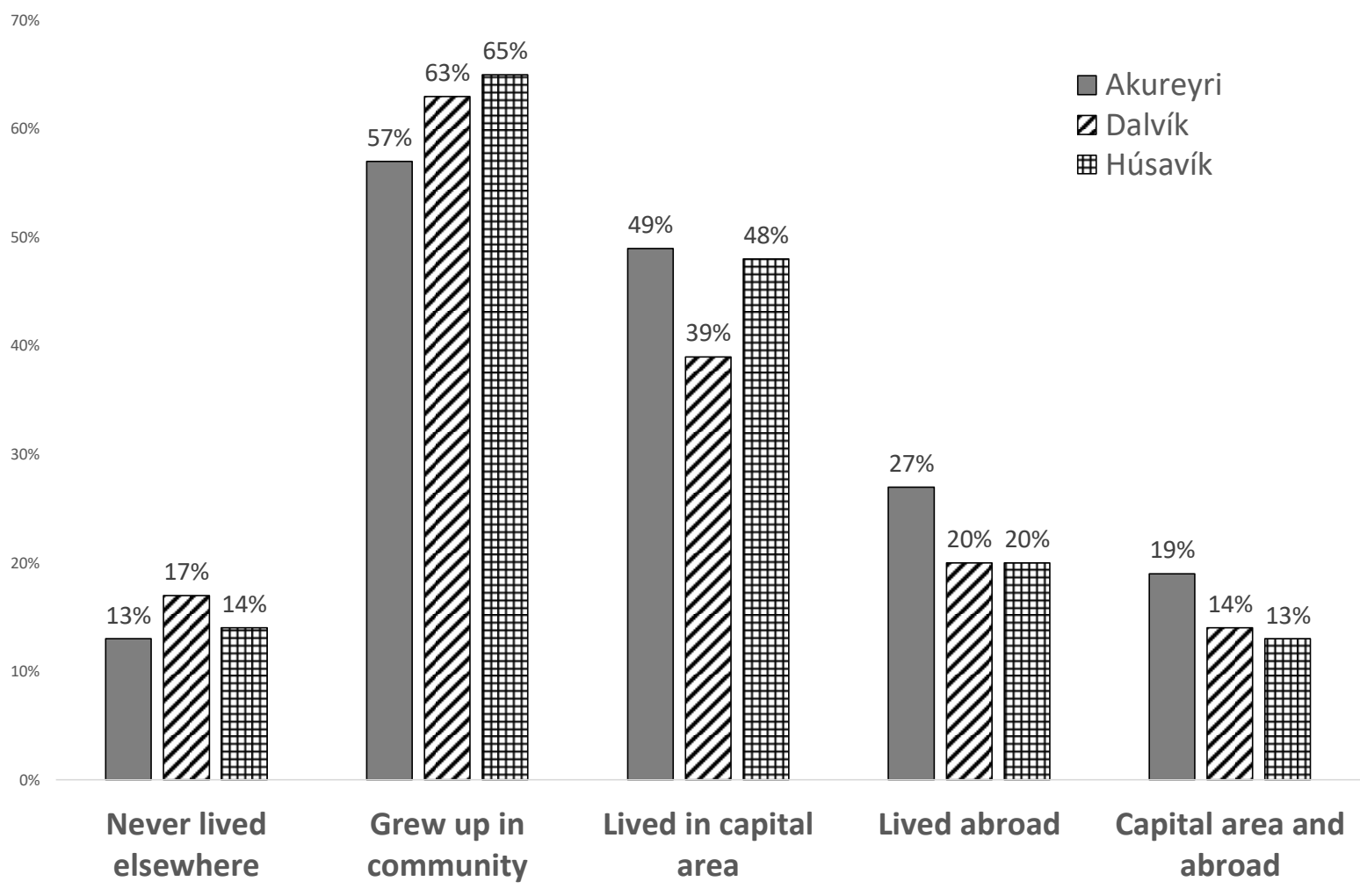

Figure 2 Mobility of residents in Akureyri, Dalvík and Húsavík 


\section{Background Variables}

Table 2 shows the results of bivariate and multivariate regression models (OLS) of tolerance towards immigrants in three communities in central Northern Iceland. Attitudes towards immigrants are significantly less tolerant in Dalvík, which also has the highest proportion of immigrants of the three communities.

Table 2

Bivariate and multivariate regression models of tolerance towards immigrants in three communities in Northern Iceland

\section{Constant}

\section{Community}

Akureyri regional centre (contrast)

Húsavík

Dalvík

\section{Origin}

Did not grow up in community (contrast)

Grew up in community

\section{Gender}

Male (contrast)

Female

\section{Age}

18-25 years old

26-40 years old

41-66 years old (contrast)

67 years old or older

\section{Education}

University education

English proficiency

\section{Employment}

Not employed

Income

\section{Attitudes}

Generalised trust

Community integration

Residential satisfaction

\section{Bivariate}

Model 1

Model 2

$6.72 * * *$

$6.47 * * *$

\section{.16}

$.25 *$

.20

$-.76 * * *$

$-.61 * * *$

$-.57 * * *$

$\begin{array}{lll}--- & --- & --- \\ -.14 * & -.03 & .08 \\ --- & & \\ .25 * * & --- & -- \\ & .10 * & .12 \\ -.07 & & \\ -.12 & -.08 & .08 \\ --- & -.41 * * * & -.28 * * \\ -.07 & --- & -- \\ & .47 * * * & .35 * *\end{array}$

$.94 * * *$

$.79 * * *$

$.54 * * *$

$.66^{* * *}$

$.65 * * *$

$.54 * * *$

$-.06$

$-.08$

$-.10$

.14

$-.08$

$-.19$

$.89 * * *$

$.19 *$

$.28 * * *$
$.70 * * *$

.13

.01

\section{Lived in capital area for year or more (interactions)}

Grew up in local community * capital

Grew up elsewhere * capital

\section{Lived abroad for year or more (interactions)}

Grew up in local community * abroad

Grew up elsewhere * abroad

$.56^{* * *}$

$.76^{* * * *}$
$.26 *$

$.35 * * *$

.12 
Those who grew up in the community are significantly less tolerant in the bivariate model, but this difference becomes non-significant in the multivariate models where mobility experiences, education and other factors are controlled.

Females are found to be more tolerant towards immigrants than males. This gender difference is however diminished in Model 1 and becomes non-significant in Model 2. Those 67 years or older were found to be significantly more tolerant and those 26-40 years old significantly less tolerant than the middle-aged control group.

\section{Education}

In line with previous studies those who had completed a university degree scored .94 units higher on the 10-point scale of tolerance towards immigrants. However a strong effect was also found for English proficiency with the tolerance score changing by 0.66 units for a two standard deviation increase in self-assessed English proficiency. In the multivariate model, an increase of two standard deviations in English proficiency was found to have a similar impact on tolerance as having a university education. Interestingly, neither employment status nor self-reported income were significantly associated with tolerance.

\section{Attitudinal Variables}

Each of the three attitudinal variables of generalised trust, community integration and residential satisfaction were found to have a positive, statistically significant bivariate association with tolerance towards immigrants. However, in the multivariate model only generalized trust remained statistically significant, representing an increase in tolerance of 0.70 units for a two standard deviation increase in generalised trust.

\section{Prior Mobility}

In line with the main hypothesis of the study those who had lived elsewhere were found to be significantly more tolerant of immigrants. In the bivariate setting, this association was slightly stronger for people who had lived abroad than those who had lived in the Reykjavík capital area, and slightly stronger for those who were originally from somewhere else than those who had returned to their home communities. Once other factors in the model had been controlled, however, the effects of having lived elsewhere were similar for returned locals and blow-ins who had lived elsewhere in Iceland or abroad.

\section{Fit of the models}

Model 1 includes measures of the community of residence, origin, gender, age, education and employment status. The adjusted $\mathrm{R}^{2}$ for Model 1 is .12 and. In Model 2, measures of attitudes and interactions between origin and migration experiences are added to the analysis. Model 2 has an adjusted $\mathrm{R}^{2}$ of .18 . While the measures employed statistically significantly predict differences in tolerance of immigrants and reduce the unexplained variance significantly, a substantial variation in such tolerance nevertheless remains unexplained.

\section{Discussion}

The contemporary urban centres of Northern Iceland now are hardly the simple, close-knit and immobile traditional $19^{\text {th }}$ century communities described by Tönnies (1887), Durkheim (1893) and Simmel (1903); they exist in a globalised world of cross-border population flows which has seen increasing numbers and proportions of immigrants from outside Iceland. At the same time, Icelanders have maintained their tradition of spatial mobility with the majority living either abroad or in the Capital Area at some time or else moving from elsewhere. Less than $20 \%$ of survey respondents had not lived elsewhere. This being so, what can be said 
about the factors associated with tolerance and positive attitudes towards immigration, and the differences between the mobile majority and the immobile minority?

Firstly, our results indicate that once other demographic and attitudinal characteristics had been taken into account, individual migratory history had a separate and additional impact on attitudes towards immigrants. In effect, migration to either Reykjavik and/or abroad by residents of the case study towns led to more positive attitudes in comparison with nonmovers from the towns. It might be expected, for instance, that those with better educational qualifications would be more tolerant (and also more mobile) and this, indeed, is the case but the model shows, for instance, that someone with a high-school education who has spent some time in Reykjavik would have a more positive attitude than a respondent equivalent in all other respects who remained in Akureyri. Furthermore, Icelanders who have lived elsewhere in Iceland or abroad or who moved to the Northern towns also have a more tolerant attitude towards immigrants and immigration than their exact immobile equivalents who had remained in the towns all their lives. It is thus possible now to assert that migration in itself has an independent association with toleration and that there are differences in attitude between the spatially immobile who remained in the Northern towns, their migratory peers, and incomers from elsewhere.

This is far from claiming causality. There is a complex nexus of associations between a basket of individual socio-demographic characteristics and spatial mobility on the one hand and the same set of characteristics and tolerance on the other (although the controls in the multivariate model deal with these as far as possible). However, there is the possibility of omitted variables that could distort the results - something which is not unique to this analysis. This omission may range from just another social/demographic characteristic - for example, political attitude or length of time abroad - but may be something more profound. There is evidence that personality traits such as extroversion and trust influence migration propensity (Jokela 2009) and that a similar suite of characteristics also influence attitudes to cross-group contact (Stürmer et al. 2013). It might thus be that migrants are selected from those who are more likely to be open to immigration anyway because of pre-existing personality traits, and these, and not the experience of mobility are what is important. There is no way to test this with the current dataset. However, we still argue that regardless of personality, that experience of spatial mobility and changing place of residence has an independent effect. There is an ample literature which indicates impacts of mobility on the identities (Hernández et al. 2007; Schmid et al. 2013) and social relations (Oishi and Schimmack 2010; Stevenson and Sagherian-Dickey, 2016) of movers. In other words, there are additional effects arising from exposure to new environments through spatial mobility.

Most other model results were as expected. Consistent with previous studies (Easterbrook et al. 2016; Hainmueller and Hiscox 2007) we find university education to be associated with more tolerance towards immigrants. It is not clear to what extent this reflects the formative effects of a university education on social attitudes or alternatively the self-selection of children of more liberal parents into higher education (Lansee \& Sarrasin, 2015).

Furthermore, language skills may facilitate communication with immigrants as well as reflecting cognitive flexibility and exposure to cultural difference and multilingualism has thus been found to predict more positive attitudes towards immigrants (Mepham and Martinovic 2018). Iceland is an interesting case in this respect as Icelandic is only spoken by about 350 thousand people in the world and is not understandable in any larger language communities. English is the dominant second language in Iceland, extensively used in communication with people from other countries. Interestingly, while many immigrants in Northern Iceland are Eastern Europeans with limited English skills, we find self-reported 
proficiency in English to have a similar effect as a university degree on tolerance towards immigrants.

The threat to job security posed by immigrants has frequently been cited as a major predictor of anti-immigration sentiments (Naumann et al. 2018; Söllner 1999) in particular in times of economic recession (Hatton 2016). Iceland has however historically had a very low unemployment rate compared to other western countries. In 2016, the unemployment in the age group 25-64 years old was 2.9\% the Reykjavík capital area and $1.6 \%$ in other regions of the country (Statistics Iceland, 2019c). The absence of any effect of either labour market participation or self-reported income on attitudes towards immigrants in our study may thus reflect a very low perceptions of economic threat from immigrants in Northern Iceland. High levels of social capital, a sense of belonging and connectedness to the local community have also been found to predict more positive attitudes towards immigration (Gordon 2015; Gordon and Maharaj 2015; Stevenson et al., 2018) as is also the case in Northern Iceland.

The literature suggests that gender and age effects vary by context, thought to reflect specific economic concerns among these groups (O'Rourke \& Sinnott, 2006). In the Northern Icelandic case, women were found to be more tolerant of immigrants than men which accords with a lower general concern with economic threat in the sample. Second, while many studies link age with less tolerance towards migrants (e.g. Bridges and Mateut, 2014; Markaki and Longhi, 2013), we find those over the age of 67 to be most tolerant of immigrants. There are several possible explanations for this pattern. First, the oldest age group may be influenced by their experiences of depopulation and decline in many areas of rural Iceland in the latter half of the $20^{\text {th }}$ century and may be keener to see population growth by immigration. Second, the oldest generations may be more aware of the importance of immigrants for various services. Third, there are strong indications that the cohorts born in Iceland in the last decades of the $20^{\text {th }}$ century hold more conservative views than older generations (Leiknisdóttir 2005) or indeed more conservative views than young people of the same age in previous decades (Bjarnason and Hjálmsdóttir, 2008).

\section{Conclusion}

This study draws together several disciplinary and thematic strands, linking empirical population geography to social psychology and social theory, and the effects of moving (or not moving) on social and cultural attitudes. The results suggest that both in-migrants and local people who have lived elsewhere are more tolerant of immigrants than those who have never left. This is interesting in the context of the recent nativist populist political turn in the USA and parts of the EU and the decline of internal migration documented since the 1970s in the USA and many European countries (Champion et al 2018). This begs the question of whether immobile populations will prove to be a fertile ground for anti-immigrant sentiments and, conversely, if leaving and later returning to the home community may counteract such sentiments.

Our results do not demonstrate causality; because of the nature of the data it is only possible to test cross-sectional associations at one moment in time. While consistent with the hypothesis that geographical mobility increases tolerance, it is possible that people with more tolerance towards cultural diversity are also more likely to be geographically mobile. The acid test would be a fully longitudinal research design that collected data for a cohort on personality traits, attitudes, and socio-demographic attributes and then obtained the same data after several years so movers and non-movers could be compared 'before and after'.

Furthermore, the design of the current study does not address the possible mechanisms underlying our main hypothesis. It is possible that individuals who are exposed to more cultural diversity develop more tolerance towards such diversity. It is even more plausible that 
the experience of having been an in-migrant in an unfamiliar domestic or foreign community leads to increased sympathy towards immigrants in one's own home community. Further quantitative and qualitative work is needed to better understand these potential mechanisms linking mobility and tolerance.

Despite these shortcomings, the analysis undertaken here adds to the corpus of evidence in an emerging research area, is consistent with the theoretical expectations of the effects of spatial immobility, and indicates a path for further research. 


\section{References}

Abrams, Dominic, and Nicholas Emler. 1992. "Self-denial as a Paradox of Political and Regional Social Identity: Findings from a Study of 16-and 18-year-olds." European Journal of Social Psychology 22: 279-295.

Amuedo-Dorantes, Catalina and Thitima Puttitanun. 2011. "Gender Differences in Native Preferences toward Undocumented and Legal Immigration: Evidence from San Diego." Contemporary Economic Policy 29: 31-45.

Andits, Petra. 2017. "The Cool Welcome and the Responses to It: Australian-Hungarians Negotiate Social Reality in Hungary after 1989.” Identities 24: 295-312.

Appadurai, Arjun. 1990. "Disjuncture and Difference in the Global Cultural Economy." Theory, Culture and Society 7: 295-310.

Bailey, Nick. 2012. "How Spatial Segregation Changes over Time: Sorting out the Sorting Processes." Environment and Planning A 44: 705-722,

Bello, Valeria. 2016. "Inclusiveness as Construction of Open Identity: How Social Relationships Affect Attitudes towards Immigrants in European Societies." Social Indicators Research 126: 199-223.

Ben-Nun Bloom, Pazit., Gizem Arikan, and Gallya Lahav. 2015. "The Effect of Perceived Cultural and Material Threats on Ethnic Preferences in Immigration Attitudes." Ethnic and Racial Studies 38: 1760-1778.

Berg, Justin A. 2010. "Race, Class, Gender, and Social Space: Using an Intersectional Approach to Study Immigration Attitudes." Sociological Quarterly: 278-302.

Bjarnason, Thoroddur and Andrea Hjálmsdóttir. 2008. "Egalitarian Attitudes Towards the Division of Household Labor Among Adolescents in Iceland." Sex Roles 59: 49-60

Bridges, Sarah and Simona Mateut. 2014. "Should They Stay or Should They Go? Attitudes towards Immigration in Europe." Scottish Journal of Political Economy 61: 397-429.

Carlson, Caroline and James G. Gimpel. 2019. "Political Implications of Residential Mobility and Stasis on the Partisan Balance of Locales." Political Geography 71: 103-114.

Catney, Gemma and Ludi Simpson, L. 2010. Settlement area migration in England and Wales: assessing evidence for a social gradient. Transactions of the Institute of British Geographers 35: 571-584.

Champion, Tony, Thomas Cooke, and Ian Shuttleworth (eds). 2018. Internal Migration in the Developed World. Routledge, London.

Du, Huimin. 2017. "Place Attachment and Belonging among Educated Young Migrants and Returnees: The Case of Chaohu, China.” Population, Space and Place 23: e1967.

Durkheim, Emile. [1893] 1933. The Division of Labor in Society. New York: The Free Press.

Dustmann, Christian and Ian P. Preston. 2007. "Racial and Economic Factors in Attitudes to Immigration." The BE Journal of Economic Analysis \& Policy, 7(1).

Easterbrook, Matthew J., Toon. Kuppens, and Anthony S. Manstead. 2016. "The Education Effect: Higher Educational Qualifications are Robustly Associated with Beneficial Personal and Socio-political Outcomes." Social Indicators Research 126: 1261-1298. 
Freitag, Markus and Carolin Rapp. 2013. "Intolerance toward Immigrants in Switzerland: Diminished Threat Through Social Contacts?" Swiss Political Science Review 19: 425446.

Goodhart, David. 2017. The Road to Somewhere: The Populist Revolt and the Future of Politics. Oxford University Press.

Gordon, Steven. 2015. "The Relationship Between National Well-being and Xenophobia in a Divided Society: The Case of South Africa." African Review of Economics and Finance 7: 80-103.

Gordon, Steven L. and Brij Maharaj. 2015. "Neighbourhood-level Social Capital and AntiImmigrant Prejudice in an African Context: An Individual-level Analysis of Attitudes towards Immigrants in South Africa." Commonwealth \& Comparative Politics 53: 197219.

Gorodzeisky, Anastasia and Andrew Richards. 2016. "Union Members' Attitudes towards Immigrant Workers: A 14-country Study." European Journal of Industrial Relations 22: 23-38.

Hatton, Timothy J. 2016. "Immigration, Public Opinion and the Recession in Europe." Economic Policy 31: 205-246.

Hernández, B., M. C. Hidalgo, M. E. Salazar-Laplace, and S. Hess.

Bernardo Hernández, M. Carmen Hidalgo, M. Esther Salazar-Laplace, Stephany Hess. 2007. "Place Attachment and Place Identity in Natives and Non-natives." Journal of Environmental Psychology 27: 310-319.

Herreros, Francisco and Henar Criado. 2009. "Social Trust, Social Capital and Perceptions of Immigration." Political Studies 57: 337-355.

Hainmueller, Jens and Michael J. Hiscox 2007. Educated preferences: Explaining attitudes toward immigration in Europe. International Organization 61: 399-442.

Jeannet, Anne M. 2018. "Revisiting the Labor Market Competition Hypothesis in a Comparative Perspective: Does Retirement Affect Opinion about Immigration?" Research \& Politics 5: 3 .

Jokela, Markus. 2009. Personality Predicts Migration within and between U.S. States. Journal of Research in Personality 43: 79-83

Lee, Neill, Katy Morris, and Thomas Kemeny. 2018. "Immobility and the Brexit Vote." Cambridge Journal of Regions, Economy and Society 11: 143-163.

Leiknisdóttir, A. M. 2005. Bradum Kemur Betri Tid: Um Vidhorf til Jafnrettismala i Upphafi 21. Aldar. Reykjavik, Iceland: University of Iceland.

Markaki, Yvonni and Simonetta Longhi. 2013. "What Determines Attitudes to Immigration in European Countries? An Analysis at the Regional Level." Migration Studies 1: 311-337.

Mepham, Kieran D. and Borja Martinovic. 2018. "Multilingualism and Out-group Acceptance: The Mediating Roles of Cognitive Flexibility and Deprovincialization." Journal of Language and Social Psychology 37: 51-73.

Naumann, Elias, Lukas F. Stoetzer, and Giuseppe Pietrantuono. 2018. “Attitudes towards Highly Skilled and Low-skilled Immigration in Europe: A Survey Experiment in 15 European Countries.” European Journal of Political Research 57: 1009-1030. 
O'Connell, Michael. 2011. "How do High-skilled Natives View High-skilled Immigrants? A Test of Trade Theory Predictions." European Journal of Political Economy 27: 230-240.

Oishi, Shigehiro and Ulrich Schimmack. 2010. "Residential Mobility, Well-being, and Mortality." Journal of Personality and Social Psychology 98: 980.

O'Rourke, Kevin H. and Richard Sinnott. 2006. "The Determinants of Individual Attitudes towards Immigration.” European Journal of Political Economy 22: 838-861.

Park, Robert E. and Ernest W. Burgess. 1925. The City: Suggestions for Investigation of Human Behavior in the Urban Environment. Chicago: University of Chicago Press.

Pettigrew, Thomas. F. 1998. "Intergroup Contact Theory." Annual Review of Psychology 49: 65-85.

Praharso, Nurul F., Morgan J. Tear, and Teagan Cruwys. 2017. "Stressful Life Transitions and Wellbeing: A Comparison of the Stress Buffering Hypothesis and the Social Identity Model of Identity Change." Psychiatry Research 247: 265-275.

Roblain, Antoine, Assad Azzi, and Laurent Licata. 2016. "Why do Majority Members Prefer Immigrants who Adopt the Host Culture? The Role of Perceived Identification with the Host Nation." International Journal of Intercultural Relations 55: 44-54.

Sassen, Saskia. 2003. “Globalization or Denationalization?” Review of International Political Economy 10: 1-22.

Schmid, Katharina, Ananthi al Ramiah, and Miles Hewstone. 2014. "Neighborhood Ethnic Diversity and Trust: The Role of Intergroup Contact and Perceived Threat." Psychological Science 25: 665-674.

Schmid, Katharina, Miles Hewstone, and Ananthi al Ramiah. 2013. "Neighborhood Diversity and Social Identity Complexity: Implications for Intergroup Relations." Social Psychological and Personality Science 4: 135-142.

Shaw, Clifford and Henry D. McKay. 1942. Juvenile Delinquency and Urban Areas. Chicago: University of Chicago Press.

Shuttleworth, Ian, Paul J. Barr, and Myles Gould. 2013. Does internal migration in Northern Ireland increase religious and social segregation? Perspectives from the Northern Ireland longitudinal study (NILS) 2001-2007. Population, Space and Place, 19: 72-86.

Simmel, Georg. [1903] 1976. "The metropolis and mental life". Pp. 409-424 in The Sociology of Georg Simmel. New York: Free Press.

Söllner, Fritz. 1999. "A Note on the Political Economy of Immigration." Public Choice 100: $245-251$.

Statistics Iceland. 2019a. Population by Urban Nuclei, Age and Sex, 1 January 2011-2018. Accessed February 12, 2019 at https://statice.is/statistics/population/inhabitants/municipalities-and-urban-nuclei/

Statistics Iceland, 2019b. Mannfjöldi í Byggðakjörnum og Strjálbýli eftir Landsvaðum Ár Hvert 1880-2015. [Population in Urban Nuclei and Spareley Populated Areas by Region Each Year 1880-2015.] Accessed February 12, 2019 at http://px.hagstofa.is/pxis/pxweb/is/Sogulegar/Sogulegar_sogul_mannfjoldi/SOG01010.px

Statistics Iceland. 2019c. Activity Rate, Employment rate, Underemployment Rate and Unemployment Rate by Year 2003-2018. Accessed February 12, 2019 at https://statice.is/statistics/society/labour-market/labour-force-survey/ 
Stephan, Walter G. 2014. "Intergroup Anxiety: Theory, Research, and Practice." Personality and Social Psychology Review 18: 239-255.

Stevenson, Clifford and Thia Sagherian-Dickey. 2016. "Collectively Coping with Contact: The Role of Intragroup Support in Dealing with the Challenges of Intergroup Mixing in Residential Contexts." British Journal of Social Psychology 55: 681-699.

Stevenson, Clifford and Thia Sagherian-Dickey. 2018. Territoriality and Migration in a Divided Society: Lay Theories of Citizenship and Place in Northern Ireland. Qualitative Psychology 5: 135-154.

Stevenson, Clifford, Matthew J. Easterbrook, Lydia Harkin, Niamh McNamara, Blerina Kellezi, and Ian Shuttleworth. 2018. "Neighbourhood Identity Helps Residents Cope with Residential Diversification: Contact in Increasingly Mixed Neighbourhoods of Northern Ireland." Political Psychology https://doi.org/10.1111/pops.12510

Stevenson, Clifford, Niamh McNamara, Matthew J. Easterbrook, Blerina Kellezi, Ian Shuttleworth, and Deborah Hyden. 2018. "Re-identifying Residential Mixing: Emergent Identity Dynamics Between Incomers and Existing Residents in a Mixed Neighbourhood in Northern Ireland." European Journal of Social Psychology https://doi.org/10.1002/ejsp.2529

Stockdale, Aileen, Marsaili MacLeod, and Lorna J. Philip. 2013. "Connected Life Courses: Influences on and Experiences of 'Midlife'In-Migration to Rural Areas." Population, Space and Place 19: 239-257.

Stürmer, Stefan, Alison Benbow, Birte Siem, Markus Barth, Alexander Bodansky, and Katharina Lotz-Schmidt. 2013. "Psychological Foundations of Xenophilia: The Role of Major Personality Traits in Predicting Favorable Attitudes Toward Cross-Cultural Contact and Exploration." Journal of Personality and Social Psychology 105: 832-851

Tönnies, Ferdinand. [1887] 1963. Community and Society. New York: Harper.

Ueffing, Philipp, Francisco Rowe, and Clara H. Mulder. 2015. "Differences in Attitudes towards Immigration between Australia and Germany: The Role of Immigration Policy." Comparative Population Studies 40: 4.

Urry, John 2007. Mobilities. Cambridge: Polity.

Van Assche, Jasper, Arne Roets, Kristof Dhont, and Alain Van Hiel. 2014. "Diversity and Out-group Attitudes in the Netherlands: The role of Authoritarianism and Social Threat in the Neighbourhood." Journal of Ethnic and Migration Studies 40: 1414-1430.

Van der Zwet, Arno. 2016. "To See Ourselves as Others See Us: Identity and Attitudes towards Immigration amongst Civic Nationalists." Journal of Ethnic and Migration Studies 42: 1242-1256.

Van Houte, Marieke, and Tine Davids. 2018. "Narrating Marriage: Negotiating Practices and Politics of Belonging of Afghan Return Migrants." Identities 25: 63 -649.

Verkuyten, Maykel, Jochem Thijs, and Hidde Bekhuis. 2010. "Intergroup Contact and Ingroup Reappraisal: Examining the Deprovincialization Thesis." Social Psychology Quarterly 73: 398-416.

Voci, Alberto and Miles Hewstone. 2003. "Intergroup Contact and Prejudice toward Immigrants in Italy: The Mediational Role of Anxiety and the Moderating Role of Group Salience." Group Processes \& Intergroup Relations 6: 37-54. 
Wilkes, Rima and Catherine Corrigall-Brown. 2011. "Explaining Time Trends in Public Opinion: Attitudes towards Immigration and Immigrants." International Journal of Comparative Sociology 52: 79-99.

Zagefka, Hanna, Rupert Brown, Murielle Broquard, and Sibel L. Martin. 2007. "Predictors and Consequences of Negative Attitudes toward Immigrants in Belgium and Turkey: The Role of Acculturation Preferences and Economic Competition." British Journal of Social Psychology 46: 153-169. 